\title{
Value of IgA human recombinant tissue transglutaminase antibody test in diagnosis of symptomatic celiac disease in children
}

\author{
Nashwan M. Al-Hafidh, Khaldoon Th. Al-Abachi \\ Department of Medicine, Nineveh College of Medicine, University of Mosul.
}

(Ann. Coll. Med. Mosul 2010; 36 (1 \& 2): 79-85).

Received: $22^{\text {nd }}$ Jun 2010; Accepted: $12^{\text {th }}$ Jan 2011.

\begin{abstract}
Objective: To identify the value of serological examination in diagnosis of celiac disease in children. Patients and methods: A prospective case series study was conducted at private clinics in Mosul city during the period from 30th of October 2007 to $30^{\text {th }}$ of October 2009. A total of 40 patients (29 males, 11 females) aged more than 6 months on gluten containing diet presented with symptoms suggestive of celiac disease were screened by serological testing using second generation ELISAs IgA human recombinant tissue transglutaminase antibody. Multiple duodenal biopsies were performed for every patient enrolled in this study regardless of the results of serology. Statistical methods were used to indicate sensitivity, specificity, negative and positive predictive values of serological test in comparison to biopsy results.
\end{abstract}

Results: A total of $16(40 \%)$ out of 40 symptomatic patients with mean age of 51 months, demonstrated both positive $\operatorname{lgA}$ anti-tissue transglutaminase antibody test and biopsy results for celiac disease, the remaining 24 patients $(60 \%)$ displayed negative results for both serology and biopsy. IgA anti-tissue transglutaminase antibody test had (100\%) specificity, sensitivity, positive predictive value, and negative predictive value in relation to biopsy results.

Conclusion: Our results provide additional support to the concept that $\lg A$ anti-tissue transglutaminase antibodies can be used as a diagnostic serologic marker for celiac disease.

الخلاصة

هدف الاراسة: معرفة قيمة الفحص المصلي في تشخيص الجو اف لدى الإس الطفال.

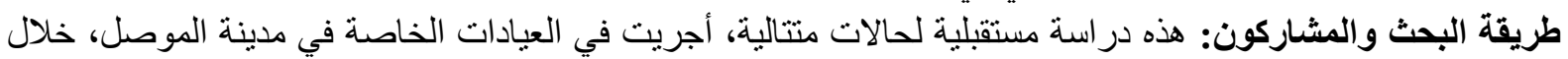

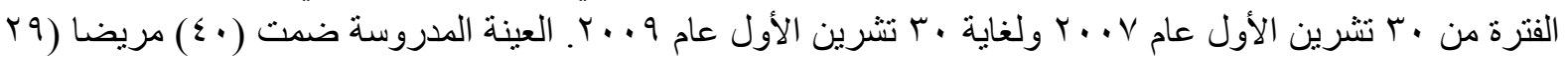

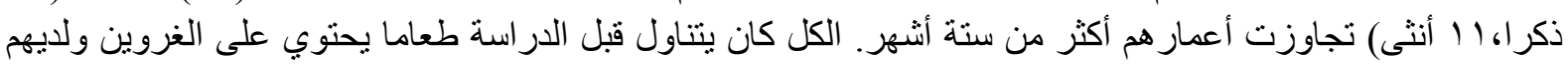

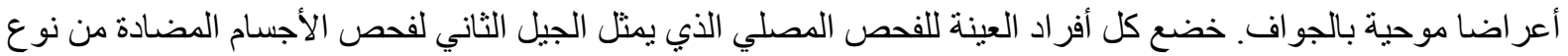
(ELISAs IgA human recombinant tTG) متعددة من الأثني عشري لكل أفراد العينة وبغض النظر عن نتيجة الفحص المصلي. أستخدمت الوسائل الإحصائية لتقييم

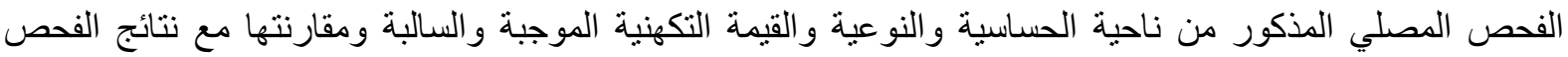

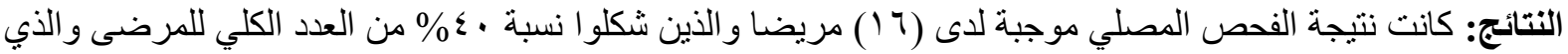

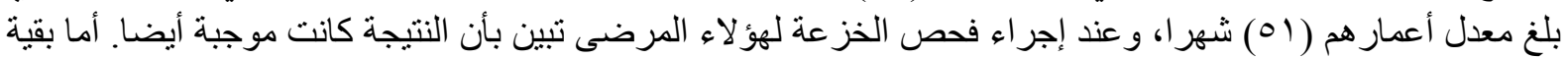

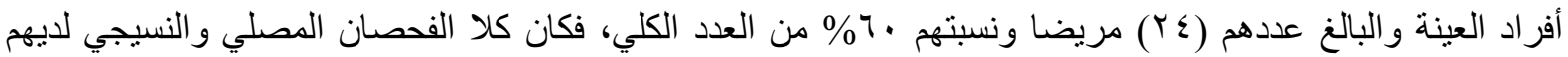




$$
\begin{aligned}
& \text { إن الفصص المصلي المذكور حقق نسبة . . 1\% فيما يخص الحساسية و النوعية والقيمة التكهنية الموجبة و السالبة بالمقارنة }
\end{aligned}
$$

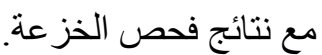

$$
\begin{aligned}
& \text { الاستتتاج: نتائج هذه الدر اسة تعطي دعما إضافيا لفكرة أن الفحص المصلي (IgA anti-tTG) من الممكن استخدامه }
\end{aligned}
$$

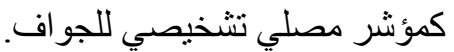

$\mathrm{T}$ he North American Society for Pediatric Gastroenterology, Hepatology, and Nutrition (NASPGHAN) recommended that children and adolescents with symptoms of celiac disease (CD) or an increased risk for CD have a blood test for antibody to tissue transglutaminase (anti-tTG) to identify individuals for whom the biopsy is indicated ${ }^{(1)}$.

Despite the increasing importance of serological methods, the diagnosis of $C D$ is still based on histological criteria ${ }^{(1,2)}$, followed by a therapeutic response to a gluten free diet $\left(\right.$ GFD) ${ }^{(3)}$.

Second generation ELISAs that detect antitTG2 IgA using human recombinant or human purified tTG2 antigen have sensitivity and specificity values ranging from $91 \%$ to $97 \%$ with the manufacturer-recommended cut-off values and are easy to perform ${ }^{(4-7)}$. As this type of analysis can be automatized, it is a valid tool in screening programs, and also is recommended for monitoring $C D$ patients on GFD ${ }^{(4)}$. Failure of the anti-tTG level to decline over a period of 6 months after starting the GFD suggests continued ingestion of gluten or related products ${ }^{(1)}$. IgA anti-tTG antibody test can be falsely negative with IgA deficiency, which is associated with an increased incidence of CD. Measurement of serum IgA concentration is mandatory to assure that false-negative results in IgA-deficient individuals are excluded ${ }^{(8)}$. Newer assays incorporating synthetic deamidated gliadinrelated peptides or other TG isoenzymes as antigen, enhances the sensitivity for detecting gluten sensitivity among non-IgA- deficient, anti-tTG seronegative patients with CD-like enteropathy ${ }^{(9)}$. A positive serological test in an individual with normal small intestinal histology may represent a false positive serological test, milder disease or a more sensitive test that identifies latent CD before mucosal injury ${ }^{(1)}$. It is important to set the lower limit of antibody titers high enough to avoid false-positive results ${ }^{(8)}$. In children with CD (87\%) younger and $(96 \%)$ older than 2 years showed high serum levels of anti-tTG2 ${ }^{(10)}$.

Definitive diagnosis of $C D$ requires small intestinal biopsy ${ }^{(8)}$. The mucosal involvement can be patchy and varies in severity, so multiple biopsies must be obtained ${ }^{(1,3,11)}$. The histologic findings in celiac disease are characteristic but not specific; indeed, celiac disease is not the only cause of villous atrophy ${ }^{(12)}$. Marsh classified the histologic changes of $\mathrm{CD}$ as Type 0 (normal), Type 1 (increased intraepithelial lymphocytes), Type 2 (Type 1+ hyperplastic crypts), Type3 (Type $2+$ variable degree of villous atrophy) and Type 4 (total villous atrophy with crypt hypoplasia) $)^{(1)}$.

Based on these facts investigators inquired the possibility of obviating the need for small intestinal biopsy which is invasive, time consuming, not free of complications, and not accepted by all patients, by assessing the value of serological test in diagnosis of $C D$.

Studies concerning different aspects of $C D$ are rare in our locality and to the best of our knowledge no similar study has been conducted in Mosul.

\section{Patients and methods}

This study was approved by ethical committee in Nineveh College of Medicine and Local Health Authority. This prospective study has been conducted at private clinics in Mosul city during the period from $30^{\text {th }}$ of October 2007 to $30^{\text {th }}$ of October 2009. Patients with suspected $\mathrm{CD}$ presenting with anorexia, failure to thrive, abdominal distention, and chronic diarrhea (in various combinations) who were aged more than 6 months and on gluten containing diet were selected.

A total of 40 patients (29 males, 11 females) with mean age of 51 months, were serologically screened by measuring $\lg A$ 
antibody to human recombinant tTG which was done by commercially available kit (AESKULISA tTG-A 3503/ Germany) a new generation of a solid phase enzyme immunoassay employing human recombinant tTG cross linked with gliadin-specific peptides display neo-epitopes of tTG. The cut-off value of the kit for a positive result is more than 15 $\mathrm{U} / \mathrm{ml}$.

For the purpose of achieving the objective of evaluation of serological data in comparison to biopsy results, and also because of unavailability of $\lg$ A level measurement for those with negative IgA anti- tTG2, all patients were subjected to duodenal biopsy regardless of the results of serology. Consents of parents of all patients were taken prior to laboratory and endoscopic examination. Upper gastrointestinal endoscopy was done in AlSalam General Hospital in Mosul city where three biopsies from different sites of duodenum were taken from every patient. Histopathologic reports were analyzed according to Marsh criteria ${ }^{(6)}$.

The validity of the serologic test and the mean age were computed through using Statistical Package for Social Sciences (SPSS, version 14).

\section{Results}

IgA anti- tTG2 test of the used kit was positive in 16 patients $(40 \%)$, all of them displayed a positive biopsy suggestive of $C D$, including three patients aged $\leq 2$ years, where as the remaining 24 patients $(60 \%)$ manifested negative serology test and normal biopsy results at the same time (Table 1). All patients with positive serology displayed March 3 histopathologic grading. In this study the lowest level of IgA anti- tTG2 that was associated with positive biopsy of $C D$ was $15.05 \mathrm{U} / \mathrm{ml}$, whereas the maximum level associated with negative biopsy was 12.75 $\mathrm{U} / \mathrm{ml}$.

Positive biopsy reports of all patients with $C D$ showed variable degree of villous atrophy consistent with the definition of Marsh type 3 histological grading.

Follow up of CD patients after starting GFD showed that IgA anti-tTG2 levels declined to normal in $14(87.5 \%)$ patients after 6 months of starting GFD. The remaining $2(12.5 \%)$ female patients, in spite of stressing on importance of strict adherence to GFD, their IgA-anti tTG2 levels remained positive after 6 months and their repeated biopsy was positive too (Table 2).

Table (1): Sensitivity, specificity, and predictive values of IgA anti- tTG2 in comparison to results of duodenal biopsy.

\begin{tabular}{|l|c|c|}
\hline \multicolumn{1}{|c|}{ IgA anti- tTG2 } & $\begin{array}{c}\text { Positive } \\
\text { biopsy }\end{array}$ & $\begin{array}{c}\text { Negative } \\
\text { biopsy }\end{array}$ \\
\hline Test positive $>15 \mathrm{U} / \mathrm{ml}$ & 16 & 0 \\
\hline Test negative $\leq 15 \mathrm{U} / \mathrm{ml}$ & 0 & 24 \\
\hline Sensitivity $=100 \%$ \\
\hline Specificity $=100 \%$ \\
\hline Predictive value of positive test result $=100 \%$ \\
\hline Predictive value of negative test result $=100 \%$ \\
\hline
\end{tabular}

Table (2): Clinical, serological, and histological follow up of 2 CD patients with persistent abnormal IgA-anti tTG2 level.

\begin{tabular}{|c|c|c|c|c|c|}
\hline \multirow{2}{*}{$\begin{array}{l}\text { Age } \\
\text { (year) }\end{array}$} & \multirow{2}{*}{$\begin{array}{c}\text { Symptoms } \\
\text { (6 months after GFD) }\end{array}$} & \multicolumn{3}{|c|}{ IgA anti-tTG2 (U/ml) } & \multirow{2}{*}{$\begin{array}{c}\text { Biopsy } \\
6 \text { months after GFD }\end{array}$} \\
\hline & & Initial & $\begin{array}{c}6 \text { months after } \\
\text { GFD) }\end{array}$ & $\begin{array}{c}7 \text { months after } \\
\text { GFD) }\end{array}$ & \\
\hline 9 & Abdominal pain & 25.45 & 29.50 & & positive \\
\hline 12 & Asymptomatic & 38.70 & 43.75 & 86.76 & positive \\
\hline
\end{tabular}




\section{Discussion}

The newly developed ELISA tests for IgA antitTG antibodies are now available and are easier to perform, less expensive than the immunofluorescence assay that is used to detect anti-endomysium IgA antibody (antiEMA); it is not subjected to inter-observer variation being investigator-independent ${ }^{(13-16)}$. The diagnostic accuracy of anti-tTG immunoassays has been improved by the use of human tTG instead of nonhuman ITG preparations ${ }^{(13)}$. It has a high sensitivity and specificity in CD, comparable to (anti-EMA) antibodies ${ }^{(17)}$. The serologic tests with the highest overall diagnostic accuracy were the tTG and the EMA, addition of HLA-DQ typing did not add to increase the diagnostic accuracy of these two tests ${ }^{(18)}$.

Our study confirms the excellent specificity $(100 \%)$ of the IgA anti-tTG2 test reported by previous studies ${ }^{(4,14,19-21)}$, and the excellent sensitivity $(100 \%)$ found in other studies ${ }^{(13,19 \text {, }}$ 22-24). Up to $100 \%$ positive predictive value was also registered ${ }^{(4,14)}$, which is identical to our finding. In the current study, the negative predictive value of $\lg \mathrm{A}$ anti-tTG2 test was $100 \%$, which was similar to Carroccio $A$ et al study result ${ }^{(22)}$. The fact that IgA anti-tTG2 titer has a good relationship with the severity of the mucosal damage of the small bowel $^{(23,25)}$, may explain the $100 \%$ sensitivity of this test in relation to Marsh 3 histopathological grading in our patients. The sensitivity of this test appears to be lower than reported when milder histologic grades are used to define $C D^{(26)}$.

In some studies high positive tTG level antibody results has not always been associated with final diagnosis of CD ${ }^{(27-29)}$. This may be attributed to false negative duodenal biopsy, probably due to patchy histopathological lesion or using guinea pig tTG which lacks specificity, and although tTG antibody positivity may appear in gastrointestinal and liver inflammatory disorders, to date, strong positive results have not been described for such conditions; in addition many of these patients may have coexistent $C D^{(30)}$.
The human tTG-based ELISA is the method of choice for easy and noninvasive screening and diagnosis of CD ${ }^{(19)}$.The presence of human anti-tTG is a reliable indicator for the diagnosis and follow-up of $C D{ }^{(2)}$. In patients with symptomatic $C D$, the presence of circulating anti-EMA or anti-tTG antibodies is highly predictive $(97 \%-100 \%)$ of biopsy changes of $C D{ }^{(31)}$. Serologic testing is important not only for screening but also for confirmation of $C D^{(32)}$.

In children $<2$ years of age, milk proteinsensitive enteropathy can produce changes similar to CD; confirmation of diagnosis after a gluten challenge and biopsy is sometimes required ${ }^{(8)}$. IgA anti-tTG2 measurements show higher sensitivity for the diagnosis of $C D$ in children older than 2 years compared with younger children ${ }^{(10)}$. In this study three patients aged $\leq 2$ years with biopsy proven $C D$ all had positive IgA anti-tTG2 levels, indicating that IgA anti-tTG2 test below two years of age may also have a high sensitivity in diagnosing CD comparable to its sensitivity above 2 years of age.

In this study the lowest level of anti-tTG that was associated with positive biopsy of CD was $15.05 \mathrm{U} / \mathrm{ml}$, indicating that the cut-off value of the used kit for a positive result which was more than $15 \mathrm{U} / \mathrm{ml}$ was appropriate value that detected all studied patients with CD. The choice of an upper cut-off limit of tTG antibody to predict accurately $C D$ or Marsh type 3 lesions may depend on the commercial kit used for tTG IgA ELISA and the cut-off value should probably be standardized in each laboratory based on experience with different kits $^{(30)}$.

Dietary non-adherence is the most common cause of unresponsive $C D{ }^{(12)}$. In the current study adherence to a GFD was observed in $87.5 \%(14 / 16)$ of CD patients, comparable results ranges from $50 \%$ to $100 \%$ were found in Middle East and North African countries ${ }^{(33)}$. The remaining $12.5 \%$ of $C D$ patients $(2 / 16)$ who manifested seropositivity after 6 months of follow up were possibly non-adherent to a GFD either intentionally or unintentionally. Histologic recovery in patients who have CD usually takes several months but can take up 
to 1 year, even if the patient remains on a strict GFD (34). Refractory CD occurs in approximately $5 \%$ of patients with $\mathrm{CD}^{(12)}$ and is defined by persistent or recurrent malabsorptive symptoms and villous atrophy despite strict adherence to a GFD for at least 6-12 months in the absence of other causes of non-responsive treated $C D$ and overt malignancy, and require additional laboratory and therapeutic intervention besides a GFD ${ }^{(35-}$ 38)

Though our study is limited by its relatively small sample size and being a private clinic based rather than hospitals or community based, the study clearly showed that anti-tTG antibody test is a highly sensitive and specific marker for $C D$ diagnosis and biopsy might not always be needed to confirm it.

\section{References}

1. Hill ID, Dirks MH, Liptak GS, Colletti RB, Fasano A, Guandalini S, et al. Guideline for the diagnosis and treatment of celiac disease in children: Recommendations of the North American Society for Pediatric Gastroenterology, Hepatology, and Nutrition. J Pediatr Gastroenterol Nutr 2005; 40: 1-19.

2. Baudon JJ, Johanet C, Absalon YB, Morgant G, Cabrol S, Mougenot JF. Diagnosing celiac disease: a comparison of human tissue transglutaminase antibodies with antigliadin and antiendomysium antibodies .Arch Pediatr Adolesc Med. 2004; 158:584-588.

3. Walker-Smith JA, Guandalini S, Schmitz J, Schmerling DH, Visakorpi JK. Revised criteria for diagnosis of celiac disease: Report of working group of European Society of Pediatric Gastroenterology and Nutrition. Arch Dis Child. 1990; 65:909911.

4. Basso D, Guariso G, Fogar P, Navaglia1 $\mathrm{F}$, Zambon CF, Plebani1 M. Insights in the laboratory diagnosis of celiac disease. Lupus 2006; 15: 462-465.

5. Van Meensel B, Hiele M, Hoffman I, Vermeire S, Rutgeerts P, Geboes K, et al. Diagnostic accuracy of ten secondgeneration (human) tissue transglutaminase antibody assays in celiac disease. Clin Chem 2004; 50: 2125-2135.

6. Collin $\mathrm{P}$, Kaukinen $\mathrm{K}$, Vogelsang $\mathrm{H}$, Korponay-Szabó I, Sommer R, Schreier E, et al. Antiendomysial and antihuman recombinant tissue transglutaminase antibodies in the diagnosis of celiac disease: a biopsy-proven European multicentre study. Eur J Gastroenterol Hepatol 2005; 17: 85-91.

7. Maki M, Mustalahti K, Kokkonen J, ,Kulmala P, Haapalahti M, Karttunen T, et al. Prevalence of celiac disease among children in Finland. N Engl J Med. 2003; 348: 2517-2524.

8. Sood MR. Disorders of malabsorption in: Nelson Textbook of Pediatrics, Kliegman RM. Behrman RE, Jenson HB, Stanton BF. 18th ed. Philadelphia: Saunders Elsevier 2007; 1591-1593.

9. Sugai $E$, Hwang $H J$, Vázquez $H$, Smecuol E, Niveloni S, Mazure $R$, et al.New serology assays can detect gluten sensitivity among enteropathy patients seronegative for anti-tissue transglutaminase. Clin Chem. 2010 Apr; 56(4):661-665.

10. Maglio M, Tosco A, Paparo F, Auricchio R, Granata V, Colicchio B, et al. Serum and Intestinal Celiac Disease-associated Antibodies in Children with Celiac Disease Younger than 2 Years of Age. J Pediatr Gastroenterol Nutr. 2010 Jan; 50(1):43-48.

11. Ravelli A, Villanacci V, Monfredini C, Martinazzi S, Grassi V, Manenti S. How Patchy Is Patchy Villous Atrophy? : Distribution Pattern of Histological Lesions in the Duodenum of Children with Celiac Disease. Am J Gastroenterol 2010; Apr 6. [Epub ahead of print].

12. Green PHR, Cellier C. Celiac disease. N Engl J Med. 2007; 357:1731-1743.

13. Sabri-Firouzi M, Omrani GR, Nejabat M, Mehrabani D, Khademolhosseini F. Prevalence of Celiac Disease in Shiraz, Southern Iran. The Saudi Journal of Gastroenterology 2008; 14(3): 135-138.

14. Heil PM, Platzer BV, Karlhofer F, Gebhart W, Huber WD, Benesch T, Vogelsang $H$, Stingl G. Transglutaminases as 
diagnostically relevant autoantigens in patients with gluten sensitivity. JDDG 2005; 3:974-978.

15. Dieterich W, Laag E, Schopper H, Volta U, Ferguson A, Gillett $\mathrm{H}$, et al. Autoantibodies to Tissue Transglutaminase as Predictors of Celiac Disease. Gastroenterology 1998; 115:1317-1321.

16. McPherson RA. Commentary: advances in the laboratory diagnosis of celiac disease. Journal of Clinical Laboratory Analysis 2001; 15:105-107.

17. Troncone R, Maurano F, Rossi M, Micillo $M$, Greco L, Auricchio $R$, et al. IgA antibodies to tissue transglutaminase: An effective diagnostic test for celiac disease. J Pediatr. 1999; 134(2):166-171.

18. Hadithi M, Von Blomberg BM, Crusius JB, Bloemena E, Kostense PJ, Meijer JW, et al. Accuracy of serologic tests and HLADQ typing for diagnosing celiac disease. Ann Intern Med. 2007; 147: 294-302.

19. Sardy M, Odenthal U, Karpati S, Paulsson M, Smyth N. Recombinant Human Tissue Transglutaminase ELISA for the Diagnosis of Gluten-sensitive Enteropathy. Clinical Chemistry 1999; (45:12): 2142-2149.

20. Bonamico M, Ferri $M$, Nenna $R$, Verrienti A, Di Mario $U$, Tiberti C.Tissue transglutaminase autoantibody detection in human Saliva: a powerful method for celiac disease screening. J Pediatr 2004; 144:632-636.

21. Fasano A. Tissue transglutaminase: The Holy Grail for the diagnosis of celiac disease, at last?J Pediatr 1999;134:134135.

22. Carroccio A, Vitale G, Di Prima L, Chifari N, Napoli S, La Russa C, et al. Comparison of Anti-Transglutaminase ELISAs and an Anti-Endomysial Antibody Assay in the Diagnosis of Celiac Disease: A Prospective Study. Clinical Chemistry 2002; (48:9): 1546-1550.

23. Akbaria MR, Mohammadkhania A, Fakherib H, Zahedic MJ, Shahbazkhania $B$, Sotoudeha MNM, et al. Screening of the adult population in Iran for celiac disease: comparison of the tissuetransglutaminase antibody and anti- endomysial antibody tests. European Journal of Gastroenterology \& Hepatology 2006; 18:1181-1186.

24. Hansson T, Dahlbom I, Hall J, Holtz A, Elfman L, Dannaeus A, et al. Antibody reactivity against human and guinea pig tissue transglutaminase in children with celiac disease. J Pediatr Gastroenterol Nutr 2000; 30:379-384.

25. Diamanti A, Colistro F, Calce A, Devito R, Ferretti $F$, Minozzi A, et al.Clinical Value of Immunoglobulin A Antitransglutaminase Assay in the Diagnosis of Celiac Disease. Pediatrics 2006; 118; 1696-1700.

26. Rostom A, Dubé C, Cranney A, Saloojee N, Sy R, Garritty C, et al. The Diagnostic Accuracy of Serologic Tests for Celiac Disease: A Systematic Review. Gastroenterology 2005; 128: 38-46.

27. Freeman HJ. Strongly positive tissue transglutaminase antibody assays without celiac disease. Can J Gastroenterol 2004; 18:25-28.

28. Fabiani E, Peruzzi E, Mandolesi A, Garbuglia G, Fanciulli G, D'Appello AR, et al. Anti-human versus anti-guinea pig tissue transglutaminase antibodies as the first-level serological screening test for celiac disease in the general population. Dig Liver Dis 2004; 36(10):671-676.

29. Chartrand LJ, Agulnik J, Vanounou T, Russo PA, Baehler P, Seidman EG. Effectiveness of antigliadin antibodies as a screening test for celiac disease in children. Canadian Medical Association journal 1997; 157(5):527-533.

30. Vivas S, Ruiz de Morales JG, Riestra S, Arias $\mathrm{L}$, Fuentes $\mathrm{D}$, Alvarez $\mathrm{N}$, et al. Duodenal biopsy may be avoided when high transglutaminase antibody titers are present. World J Gastroenterol. 2009 October 14; 15(38): 4775-4780.

31. Hoffenberg EJ, Emery LM, Barriga KJ, Bao F, Taylor J, Eisenbarth GS, et al. Clinical features of children with screening-identified evidence of celiac disease. Pediatrics 2004; 113: 1254-1259.

32. Ashabani A, Errabtea $H$, Shapan A, Tuckova L, Tlaskalova-Hogenova $\mathrm{H}$. Serologic markers of untreated celiac 
disease in Libyan children: antigliadin, antitransglutaminase, antiendomysial, and anticalreticulin antibodies. j pediatr gastroenterol nutr. 2001 Sep; 33(3):276282.

33. Barada K, Bitar A, Mokadem MAR, Hashash JG, Green P. Celiac disease in Middle Eastern and North African countries: A new burden? World J Gastroenterol. 2010 March 28; 16(12): 1449-1457.

34. Krauss N, Schuppan D. Monitoring nonresponsive patients who have celiac disease. Gastrointest Endosc Clin N Am. 2006 Apr; 16(2):317-327.

35. Rubio-Tapia A, Murray JA. Classification and management of refractory celiac disease. Gut. 2010 Apr; 59(4):547-557.
36. Al-Toma A, Goerres MS, Meijer JW, von Blomberg BM, Wahab PJ, Kerckhaert JA, et al. Cladribine therapy in refractory celiac disease with aberrant $T$ cells. Clin Gastroenterol Hepatol. 2006 Nov; 4(11):1322-1327.

37. Goerres MS, Meijer JW, Wahab PJ, Kerckhaert JA, Groenen PJ, Van Krieken $\mathrm{JH}$, et al. Azathioprine and prednisone combination therapy in refractory celiac disease. Aliment Pharmacol Ther. 2003 Sep 1; 18(5):487-494.

38. Mulder CJ, Wahab PJ, Moshaver B, Meijer JW. Refractory celiac disease: a window between coeliac disease and enteropathy associated $\mathrm{T}$ cell lymphoma. Scand $\mathrm{J}$ Gastroenterol Suppl. 2000; ( 232):32-37. 